\title{
What's the role of humanities in academic reading and writing processes? Martha Nussbaum and François Rastier ${ }^{1}$
}

Fecha de recepción: 17 de febrero de 2016 Fecha de aprobación: 28 de marzo de 2016 Pp. 27-44

\author{
Andrea Torres Perdigón \\ Pontificia Universidad Javeriana - Bogotá \\ atorresp@javeriana.edu.co
}

Cómo citar este artículo: Torres, A. (2016). What's the role of humanities in academic reading and writing processes? Martha Nussbaum and François Rastier. Comunicación, cultura y política, 7 , pp 27-44

\begin{abstract}
This article presents a reflection on the role that the humanities could play in supporting possible reading and writing difficulties that are currently experienced by university students in a global context. It begins by examining the issues emerging in the Spanishspeaking world and proposes a possible change in our concept of knowledge in universities. This transformation is explored in two essays, one by Martha Nussbaum (2010) and the other by François Rastier (2013). A comparative analysis of these two texts allows to establish a common basis on the role that these sciences can have in a university facing the consequences that the changes in the conception of knowledge could generate in the higher education.
\end{abstract}

\section{Keywords}

Humanities, academic writing, François Rastier, Martha Nussbaum, academic literacy.

1 First published in Spanish. Reference: Torres Perdigón, A. (2016). ¿Qué papel juegan las humanidades en la lectura y escritura universitarias? Martha Nussbaum y François Rastier. Íkala, Revista de Lenguaje y Cultura, 21(3), 313-323. doi: 10.17533/udea.ikala.v21n03a07

2 Doctora y magíster en Estudios Romances Hispánicos por la Universidad París Sorbona (París IV), y profesional en Estudios Literarios por la Pontificia Universidad Javeriana de Bogotá. Actualmente es coordinadora del Centro de Escritura de la Universidad Javeriana, donde enseña lengua materna y literatura. Es autora del libro La littérature obstinée: le roman chez Juan José Saer, Ricardo Piglia et Roberto Bolaño (2015), así como de diversos artículos sobre alfabetización académica, literatura hispanoamericana contemporánea, teoría literaria, y narratología estructuralista y posclásica. ORCID: http://orcid.org/00000003-2539-4766 


\section{¿Cuál es el papel de las humanidades en los procesos académicos de lectura y escritura? Martha Nussbaum y François Rastierel}

\section{$\underline{\text { Resumen }}$}

Este artículo presenta una reflexión sobre el papel que las humanidades podrían tener en el apoyo a las posibles dificultades de lectura y escritura que experimentan los estudiantes universitarios en un contexto global en la actualidad. Comienza examinando los problemas que se plantean en el mundo hispanoparlante y propone un posible cambio en el concepto que tenemos del conocimiento en las universidades. Esta transformación se explora en dos ensayos, uno de Martha Nussbaum y otro de François Rastier. Un análisis comparativo de estos dos textos permite establecer una base común sobre el papel que estas ciencias pueden tener en una universidad frente a las consecuencias que los cambios en la concepción del conocimiento podrían generarse en la educación superior.

\section{Palabras clave}

Humanidades, escritura académica, François Rastier, Martha Nussbaum, alfabetización académica.

\section{Quel est le rôle des Sciences Humaines dans les processus académiques de lecture et d'écriture? Martha Nussbaum et François Rastier}

\section{Résumé}

Cet essai théorique porte sur les variations des modes de lecture et d'écriture dans un contexte académique et sociétal. La formation idéologique y est considérée comme un recours d'importance dans la présentation de la lecture et de l'écriture dans ces deux contextes. La formation des idées prend son origine lorsque les concepts de Bakhtin d'idéologie (système d'idées) et de dialogue se convertissent en principes directeurs des pédagogies s'intéressant aux processus de lecture et d'écriture. Ce texte aborde les différentes idéologies des processus d'écriture (traditionnel, expressivo-cognitive, socio-epistémique) et conclut que la philosophie socio-epistémique exprimée au travers de la pédagogie des styles d'écriture répond davantage aux concepts d'idéologie et de dialogue, plus à même de développer les processus de lecture et d'écriture de la formation idéologique.

\section{Mots clés}

Sciences humaines, écriture académique, François Rastier, Martha Nussbaum, alphabétisation académique. 


\section{Qual é o papel das humanidades nos processos de leitura e escrita acadêmica? Martha Nussbaum e François Rastier}

\section{Resumo}

Este artigo apresenta uma reflexão sobre o papel desempenhado pelas ciências humanas no apoio às possíveis dificuldades de leitura e escrita vivenciadas pelos estudantes universitários em um contexto global atualmente. Este artigo começa examinando os problemas que surgem nos falantes da língua espanhola e sugere uma possível mudança no conceito de conhecimento existente nas universidades. Esta transformação é explorada em dois ensaios, um de Martha Nussbaum e outro de François Rastier. Uma análise comparativa desses dois textos pode estabelecer um terreno comum sobre o papel que estas ciências podem ter na universidade frente as consequências que a mudança na concepção do conceito de conhecimento poderia gerar no ensino superior.

\section{Palavras-chave}

Humanidades, escrita acadêmica, François Rastier, Martha Nussbaum, alfabetização acadêmica. 
Leur objectif principal, décrire dans toutes ses dimensions, par la méthode historique et comparative, la diversité des sociétés et des cultures, peut passer pour hostile à la mondialisation économique, ne serait-ce que parce qu'elles se refusent à réduire les sociétés à des économies

François Rastier, (2013, p. 88)

\section{Introduction}

Towadays, teachers working in higher education in several countries 1 have experienced - with considerable uneasiness and concern- multiple reading and writing difficulties in university students. In this respect, and in the Spanish-speaking context, it is possible to trace this concern back to more than a decade, as seen in the research by Paula Carlino (Carlino, 2005, 2013; Carlino and Fernández, 2010), in Argentina or most recently in Mexico, from special journals devoted to this problem, for example, the thematic section coordinated by Alma Carrasco Altamirano, María Teresa Fátima Encinas Prudencio, María Cristina Castro Azuara and Guadalupe López Bonilla (2013). In Colombia, the events that have been organized by Redlees (Network for Reading and Writing in Higher Education) since 2007, as well as the inter-university research coordinated by Mauricio Perez Abril and Gloria Rincón Bonilla (2013) or by Blanca Yaneth González Pinzón and Adriana María Salazar-Sierra (2015), and individual studies by Andrade (2009), show the magnitude of this concern and how widespread difficulties in reading and writing seem to be in public and private universities. In tune with these concerns, the writing centers are multiplying and institutional initiatives to support university students through mentoring and various academic literacy materials have doubled.

Nevertheless, further from the diagnostic of this situation in several countries and the supporting tools that writing centers provide (inspired in the majority by writing centers in the US), it is worth to ask for the possible explanations to this situation. However, looking beyond the mere findings, it will be possible to investigate the causes and propose actions that are not just restricted to individual advice, that is to say, actions that can propose solutions within the educational models, and that go beyond the immediacy of the advisory sessions. 
A specific approach that has raised a different conception to writing corresponds to the perspective of Writing Across the Curriculum (WAC), which proposes an integration of reading and writing in the various disciplinary fields at the university. This movement intended to be separated from the concept of writing as an exclusively transversal skill:

Thus the Writing Across the Curriculum (WAC) movement was formed $[\ldots]$, as a response to the limitations of the notion of writing as transversal and writing skill as easily transferrable (Russell, 2013, p. 164).

This transversal approach to writing, that is to say, as a basic skill that is transferred and reproduced in any discipline, was considered as one of the possible causes of the difficulties experienced by university students. This movement contemplated the incorporation of writing in multiple courses in the curriculum, in order to foster a specialized concept of the writing skills within each discipline. According to Russell, Lea, Parker, Street and Donahue "the term WAC means efforts to improve students' learning and writing (or learning through writing) in all university courses and departments (with some attention to school and adult education as well)" (2009, p. 395).

Although this alternative begins with an intervention across the curriculum and, to that extent it affects the educational models, this article seeks to reflect on a number of assumptions that precede this type of action, and perhaps justify both conceptions of transversal and specialized writing at the university level. This is based on a series of circumstances that could explain the current situation, and thus provide greater clarity about the difficulties of reading and writing to enrich initiatives that try to address this situation.

However, while the reasons that explain this situation most probably obey complex problems of various natures - technological, historical and ideological-, it may be prudent to first explore the university environment and level of knowledge that permeates the institution. In other words, before searching for an explanation on new technologies or the use of digital media by new generations entering higher education, we propose to think first about the area(s) in which this issue is seen more closely and clearly: in university education. 
Within this general inquiry about the propagation of knowledge within universities, we then propose to question the role of the humanities with respect to this situation. What role do social sciences and the disciplines related to arts and languages play or have played in the development of reading and writing skills? Is there any specific contribution that these fields of knowledge can make to university education processes in other areas of knowledge or other careers? What status is given to these disciplines in universities today? Can that status have any connection with what appears to be a growing functional illiteracy of professionals and with the difficulties of some students to develop an autonomous, creative and critical thinking? Is there a change in the current approach to knowledge that can be related to the difficulties experienced by students every day? If so, what role can the humanities have in this transformation, or at least in pedagogical practices that succeed in improving the reading and writing skills and simultaneously, stimulate thinking of university students?

The choice of humanities as a field of study related to reading and writing obeys the following intuition: it is likely that there is a transformation taking place towards the approach of knowledge circulating in universities. In this current approach, the humanities seem to have lost their position; the knowledge of human sciences is considered expendable, unless it is captured or used for economic means. This transformation in the approach of what we might call the academic knowledge, which seems to dominate some changes in institutional policies in universities, along with a progressive marginalization of the humanities in programs and curricula, could be related to student's difficulties with reading and writing.

The reflection that we present in the following pages intends to explore the possible role of the humanities in the current context of reading and writing difficulties at university level. In particular, it aims to analyze two texts that have established the relationship between humanities and these two basic skills for learning any area of knowledge. It concerns, on the one hand, the book Not For Profit: Why Democracy Needs The Humanities, by the American philosopher Martha Nussbaum, published in English in 2010; and, on the other, Apprendre pour transmettre. L'éducation contre l'idéologie managériale (Teaching to transmit, education against the ideology of management of companies), by the French linguist François Rastier, published in 2013. Both 
books, despite the differences in their approaches, discuss the possible role that the humanities fulfill on the subject that both consider a current crisis in education (in democratic and capitalist countries, especially United States, India, and France). The crisis that these two authors mention, make reference to the criteria governing what is taught and considered as knowledge within higher education today. Let us see the comparative reading of these positions from two different contexts, the European and the US, in order to establish some elements of analysis in these circumstances.

\section{Nussbaum: Socratic pedagogy and culture of empathy}

Tor Nussbaum, the crisis in education is evident, as well as its political implications for the stability of democracy:

Radical changes are occurring in what democratic societies teach the young, and these changes have not been well thought through. Thirsty for national profit, nations, and their systems of education, are heedlessly discarding skills that are needed to keep democracies alive (Nussbaum, 2012).

The skills that Nussbaum points at are related to the content that is taught in the social sciences, and in the arts and languages, that is to say, in the global area that is commonly denominated humanities in the Anglo-Saxon context. According to her thesis, particularly in the United States of America and India, the institutions of higher education are gradually moving away from teaching these disciplines, which would imply a risk to democratic values. Following Nussbaum's argument, the emphasis on education for economic development exclusively focuses on the teaching of science and technology, but runs the risk of neglecting "[...] the ability to think critically; the ability to transcend local loyalties and to approach world problems as a "citizen of the world"; and, finally, the ability to imagine sympathetically the predicament of another person" (Nussbaum, 2012). 
According to the author, these skills are developed in a privileged way in humanities. Indeed, the inability to develop critical thinking, as well as an ethical and respectful awareness of cultural differences can compromise democracies. The lack of autonomy and of individual thought can produce easily manipulated citizens, some irrational political decisions and submission towards figures of authority with little respect towards multiplicity and difference. Moreover, today it is clear that "producing economic growth does not mean producing democracy. Nor does it mean producing a healthy, engaged, educated population in which opportunities for a good life are available to all social classes" (Nussbaum, 2012). If so, the situation of many developed and emerging countries in terms of social equality would be different. For this reason, an educational model based on economic growth probably needs more technical and technological training for the future obedient and operative employees, as opposed to people with developed critical thinking or truly entrepreneurial and innovative spirit. Given this scenario, the role that the humanities can perform, according to the American philosopher, is precisely to cultivate that critical thinking in students; and not because it is a useful and immediate economic resource for future professionals, but because it promotes the formation of citizens prone to democracy.

With regard to this problem, we can briefly state that Nussbaum's fundamental concern, besides the political component of a democracy at risk, focuses on developing ethics, understood as the understanding and empathy for others. Her analysis starts from a philosophical and developmental psychology perspective, a kind of primal story that would be common to the childhood of human beings:

Particular social and political structures make a big difference to the outcome of these struggles, but we would do well to work, at least tentatively, with a widely shared narrative of human childhood, in order to locate within it problems and resources that both institutions and social norms can further develop or inhibit (Nussbaum, 2012).

In this story, the initial narcissism of a child and the feelings of shame and disgust at their own helplessness and fragility can be channeled by certain social norms that are directly related to education. The purpose of this educational addressing could prevent such "primitive" feelings from flowing 
into and moving towards social hierarchy and, above all, to the stigmatization of those considered different from their own group. In Nussbaum's words, "In this way, the narcissistic child's original desire to turn parents into slaves finds fulfillment - by the creation of a social hierarchy. This dynamic is a constant threat to democratic equality" (Nussbaum, 2012).

Hierarchy and social exclusion would have, following this common primitive story, an explanation on the psychological reaction to one's own vulnerability, reinforced by social transmission of that fear and disgust towards the unknown, "so the sources of social hierarchy lie deep in human life; the 'internal clash' can never be fought on the terrain of the school or university alone, but must involve the family and the larger society" (Nussbaum, 2012).

Education therefore, for this author, has a key role - but not exclusive against anti-democratic trends in social hierarchy. Thus, with the orientation that seeks to segregate, Nussbaum's reflection focuses on a particular interest: cultivating the understanding and empathy for other individuals.

For her, the contribution of the humanities to critical thinking and the formation of democratic citizens are visible mainly from two elements: teaching methods of certain disciplines on the one hand, and the cultivation of empathy through the arts on the other. For this reason, we shall not dwell on this "primitive" narrative from developmental psychology, or its consequences for general ethics. But we are interested, with respect to the first element, in keeping the idea of critical thinking linked to the teaching of humanities and to methods resulting from these disciplines, such as the Socratic pedagogy, to which the author devotes a specific chapter. In particular, the central place of argumentation in areas such as philosophy could be set up in other fields of education. Nussbaum points out that linking Socratic pedagogy to education could be done through the incorporation of "[...] critical thinking should be infused into pedagogy of classes of many types, as students learn to probe, to evaluate evidence, to write papers with well structured arguments presented to them in others texts" (Nussbaum, 2012).

While these forms of work are commonly related to the analysis and production of arguments in disciplines such as philosophy, history and literary studies, they do not appear to be widespread in other areas of knowledge. 
Hence, it is the suggestion of the American author to take up such methods and bring the student to critical thinking and at the same time, to a respectful attitude towards the unknown, the multiplicity and the difference.

Regarding the second element, Nussbaum sees two specific advantages in teaching arts:

In other words, the role of the arts in schools and colleges is two-fold. They cultivate play and empathy in a general way, and they address particular cultural blind spots. The first role can be played by works remote from the student's own time and place, although not just any randomly selected work. The second requires a more pointed focus on areas of social unease (Nussbaum, 2012).

Regarding "blind spots", Nussbaum refers to situations of social discomfort that, according to her idea, the arts identify, show, represent, and rework, so that there would be a function of reworking the social conflict in music, dance, or literature. In addition to the development of empathy, the arts are then assigned the role of highlighting certain discomforts of each culture.

Regarding this last point, a caveat must be raised: although Nussbaum's position defends the role of art, this does not mean that we think that the simple approach to the arts and humanities is guarantor of the education of individuals that are ethical and respectful of the difference. This ethical education also depends on other irreducible principles to the aesthetic realm or the study of phenomena that occurs in the social sciences. In other words, and from our point of view, just by emphasizing on arts and humanities does not necessarily guarantee the education of ethical or even democratic beings; however, we want to point out that education in these disciplines can itself imply an approach to a critical and independent thinking which, although necessary, may not be sufficient for the development of an ethical behavior. Arts can contribute to the formation of the ethics of empathy, but does not guarantee that this takes place or is reduced to the social role of pointing out discomforts. 
The general outline of Nussbaum's text, in terms of the role of the humanities in the construction of critical thinking in the context of universities, is inseparable from reading and written production of students. We now turn to a second perspective on the same issue.

\section{Rastier: training or educating?}

Tn his address, the French linguist François Rastier outlines his concerns identifying an even more concrete aspect of this crisis of the education that, according to him, is also happening in Europe. From the text, the phenomenon is even more explicit: the ideology of corporate governance is progressively encroaching educational models. In the words of Rastier:

Here, we will understand by ideology of business management, a general conception of the social universe with purely economic objectives, based on the maximum profitability in short-term, and whose administrative methods, modeled on large companies, are used in the coercive way of what is known as soft power (Rastier, 2013, p. 11).

As you can see, what Nussbaum calls an education for economic development, for Rastier it reciprocates with an ideology of business management (idéologie managériale), according to all dimensions of social life, including education, can be strictly understood in terms of short-term and economic goals. Now, against this omnipresence of the management discourse, Rastier also refers to the social sciences as a field of knowledge that is not only incompatible with this ideology, but which also holds resistance. In these sciences, there is a conception of knowledge and culture that disagrees with the administrative discourse: "it is a certain conception of knowledge and culture that is at stake: restricted, instrumented, mainly opposing both what is acquired as well as the objectives of social science" (Rastier, 2013, p. 24). Knowledge, as understood in the social sciences, is not compatible with the instrumented concept from management ideology: it is from another order. 
Unlike Nussbaum, it is not so much that the notions of culture and knowledge of humanities are being marginalized by the preponderance of science and technology, but what is meant by knowledge in the social sciences, the arts, and languages are incompatible with what the ideology of management meant by "training".

At this point, Rastier (2013, p. 26) makes a distinction between training and education that is relevant to clarify this change in approaches of what it means to know and, therefore, what should be taught in the academic field.

As for training, it is about acquiring procedures in which there is not necessarily an integral autonomy in training - in the sense of "training" that is given to an employee in any industry or company. For example, they are taught a series of procedures to carry out some specific action. Education, however, requires knowledge that is constantly reworked and contextualized; it is the transmission of knowledge that implies autonomy, critique, and adaptability on the part of the learner. According to Rastier, in the case of training, "operators are indoctrinated to learn rules that should be internalized and implemented, but it is not, in any way, to develop a critical mind" (Rastier, 2013, p. 27). For the French linguist, education obeys, instead, to other types of work with the knowledge and autonomy, as well as with the possibility of an own critical thinking: "to present a topic, we need to decentralize our point of view, try to objectify it, find new arguments, and perceive that we thought we knew, as an ignorant that is more literate than others" (Rastier, 2013, p. 36). Hence the author sees the ideology of business management and education as incompatible: whilst training teaches specific and determined procedures that are learnt once and for all, education involves broad autonomy and the promotion of critical, adaptive, and creative thinking.

According to this author, "Learning is, in this way, to confront otherness: the effort of adaptation requires a critical outlet, a way out from prejudice, which goes against the everyday experience of students" (Rastier, 2013, p. 55). This exit from self-prejudice and the ability to adapt means that education is not based on fixed content that can be replicated, but in a process that involves distancing from your own thinking. The mere teaching of contents or specific procedures can provide practical and mechanical tasks in the world of management, but not the development of critical and complex thought. 
This distinction between training and education may show a focal point in the transformation of the conception of knowledge in the university. Perhaps the emphasis on training is leaving aside the concern for autonomy and critical capacity of the student, a characteristic of education in a broader sense. If so, the scenario in which both students and teachers are more focused on learning practical procedures that in the development of individual thought could partially explain the current difficulties in reading and writing.

However, the crisis in education acquires, for Rastier, a greater dimension than for Nussbaum. While both authors agree in warning on the risks towards democracy, "If we are content to form consumers and taxpayers, we endanger democracy because we strip the citizens of the ability to govern and be governed" (Rastier, 2013, p. 31), Rastier sees an even more serious problem in the literacy difficulties. The author claims that the difficulties in reading and writing, as well as in calculation, involve not so much knowledge itself, but basic conditions to learn other skills, "basic skills (reading, writing, and counting) remain at the primary level: they are not skills strictly speaking, but conditions of their acquisition" (Rastier, 2013, p. 31).

Thus, student's reading and writing difficulties are not only a failure in areas of knowledge that would have to do exclusively with the language and humanities, but involve general learning problems. Hence this issue of university literacy is not just an isolated aspect that can be solved with an intensive writing course; it is related to learning difficulties in general, and the development of an autonomous and critical thinking.

In this context, the humanities fulfill not only a key role in education in terms of worked content - as an approach to the concept given to society or culture, for example-, but also in relation to the development of thought that generates its ways of working and methods. This is because their objects of study have to do with the configuration of sense: "It has been rightly said that they were the sciences of sense, without doubt to emphasize the interpretative and reflective dimensions. But the sense is made of differences - and not from reference to preconceived ontologies" (Rastier, 2013, p. 136). By working from the sense and when demanding irreducible interpretative tasks to the simple communication of contents, the arts, literature, and social sciences have developed methodologies that could be essential for 
the improvement of general learning, as well as specific reading and writing skills at university level.

For this reason, the defense of the field of humanities is crucial to Rastier, to the extent that these disciplines are the ones that promote both thinking and developing these skills that are essential in learning. Thus, the problem is not only that they are marginalizing the humanities and they will disappear; what is most troubling is that these disciplines stimulate reading and writing skills that are essential for any learning process. Being displaced, the stimulus of those skills may be as well. This shift and the predominance of training, above education, are related, from the perspective of Rastier, with a growing illiteracy in contemporary culture.

The question then would be if the loss of a particular place of humanities at universities, as well as a gradual adoption of administrative principles in the educational discourse -in detriment of interpretive and reflective methods characteristic of the disciplines working with the sense- can give some light to the recurring difficulties in reading and writing of students.

\section{Conclusion}

W hile Nussbaum addresses the issue from the defense of ethics and arts, and Rastier from the claim of languages and literatures, both authors see a similar political danger in the progressive marginalization of the humanities in the programs of higher education. Both also note that this marginal role seems to be related to increasing functional illiteracy and with possible difficulties in the development of critical thinking.

Despite the differences between the two contexts; the one from American education, primarily private and quite expensive, and the one from the French public education, we then have a common problem of the globalized world: the progressive abandonment of the humanities in higher education may be related to difficulties in reading and writing, as well as representing a threat to Western democracies. 
This common problem allows us to think about an additional aspect concerning what is happening in Colombian universities with regards to reading and writing of students. We are probably witnessing a change in the approach to knowledge within universities: perhaps, and retaking the distinction from Rastier, training in some cases is replacing education, through ideologies that seek to place emphasis on practicality or immediacy of what someone is taught. So, the fact of conceiving knowledge as the acquisition of procedures and not as knowledge that is permanently reformulated, perhaps is stopping to stimulate learning autonomy and critical thinking of students. The point is that this critical and creative thinking is a skill that is still wanted in professionals from multiple disciplines, not only teachers and academics. Then, it is expected that professionals have a critical thought but, is it possible that the disciplines, content, and practices that could encourage that thought are being moved or ignored in the classroom?

In particular, with regard to reading and writing, it is worth considering whether there is any relationship between learning difficulties and the increasing use of the "genders" of management (as Rastier calls it) in classrooms, as for example, keywords, questionnaires and Power Point. These genders require, in effect, a minimum level of articulation of the worked contents. Could it be possible that the increasingly widespread use of these tools and the abandonment of more thoughtful and complex writing practices have a relationship with the state of reading and writing today? Could these changes be related to the current crisis?

Perhaps the humanities, working from culture, sense, and critique, could provide some reflective practices that nurture these learning processes in other disciplines. In any case, it could be that the causes of the crisis in education described by the two authors are not exclusively related to technological changes, as it may have been initially thought. Perhaps there is a more profound change in the approach of what should be transmitted in the universities and even what it means to transmit knowledge. Therefore, in addition to the figure of individual counseling, writing centers and material support, it is important to think about deeper changes in classroom practices. It can be an important route to confront the situation with reading and writing at university level in the contemporary world. 
We began this reflection considering whether the humanities could contribute something to the current situation with reading and writing in universities. From that point, we went onto a hypothesis that involves a possible change in the approach to knowledge within the university. From a panoramic reading of two texts, one by Martha Nussbaum and another one by François Rastier -from a philosophical and linguistic perspective, respectivelyit was possible to identify some changes involving the marginalization of the humanities in the higher education system and a predilection for training in specific procedures over education to promote autonomy and critical thinking. These changes are due to institutional policies and the ideology of business management that seems to be established as an educational paradigm.

Now, if there is a change in the approach to university knowledge, it is probably more noticeable in the following: university policies and forms of education seem to be adopting a synchronic vision of reading and writing skills. This means that, in addition to thinking of them as purely transversal, they are identified with skills that can be developed without regard to their own diachronic dimension. Thus, reading and writing are sometimes conceived as skills without history that, therefore, can be manipulated for concrete and exclusively pragmatic purposes. Meanwhile, the fact that this synchronous conception flows between different university programs is almost contradictory with regards to the historic and comparative nature of these two skills, as well as its close relationship with the meaning and the characteristics of each language. Perhaps the articulation of a historical and non-instrumental conception of reading and writing initiatives such as writing centers, with projects such as writing across the curriculum and the initial courses for reading and writing at universities, would improve the outcomes of students and, above all, focus its training towards building a tolerant and truly multicultural citizenry, as opposed to the operational skills for specific tasks and purposes. 


\section{References}

Andrade Calderón, M. C. (2009). La escritura y los universitarios. Universitas Humanistica, 68(68). Retrieved from http://revistas.javeriana.edu.co/ index.php/univhumanistica/article/view/2277.

Carlino, P. (2005). Escribir, leer y aprender en la universidad. Una introducción a la alfabetización académica. Buenos Aires: Fondo de Cultura Económica.

Carlino, P. (2013). Alfabetización académica diez años después. Revista Mexicana de Investigación Educativa, 18(57), pp. 355-381.

Carlino, P., \& Fernández, G. (2010). ¿En qué se diferencian las prácticas de lectura y escritura de la universidad y las de la escuela secundaria? Lectura y Vida, 31(3), pp. 6-19.

Carrasco Altamirano, A., Encinas Prudencio, M. T. F., Castro Azuara, M. C., \& López Bonilla, G. (2013). Lectura y escritura académica en la educación media superior y superior. Revista Mexicana de Investigación Educativa, 18(57), pp. 349-354.

González Pinzón, B. Y., Salazar-Sierra, A. M., \& Peña Borrero, L. B. (2015). Formación inicial en lectura y escritura en la universidad. Bogotá, D. C: Pontificia Universidad Javeriana.

Nussbaum, M. C. (2012). Notfor Profit. Why Democracy needs the Humanities [e-reader version]. Princeton, NJ: Princeton University Press.

Pérez Abril, M., \& Rincón Bonilla, G. (Eds.). (2013). ¿Para qué se lee y escribe en la universidad colombiana? Un aporte a la consolidación de la cultura académica del país. Bogotá, D. C.: Pontificia Universidad Javeriana.

Rastier, F. (2013). Apprendre pour transmettre. L'éducation contre l'idéologie managériale. París: Presses Universitaires de France. 
Russell, D. R. (2013). Contradictions regarding teaching and writing (or writing to learn) in the disciplines: What we have learned in the USA. Revista de Docencia Universitaria, 11(1), 161-181.

Russell, D. R., Lea, M., Parker, J., Street, B., \& Donahue, T. (2009). Exploring notions of genre in "academic literacies" and "writing across the curriculum": Approaches across countries and contexts. In C. Bazerman, A. Bonini, y D. Figueiredo (Eds.), Genre in a Changing World (pp. 395423). Fort Collins and West Lafayette: The WAC Clearinghouse and Parlor Press. 